\title{
Enhanced performance of dye-sensitized solar cell with thermally stable natural dye-assisted $\mathrm{TiO}_{2} / \mathrm{MnO}_{2}$ bilayer-assembled photoanode
}

\author{
Shyamal Datta ${ }^{1} \cdot$ Argha Dey $^{1} \cdot$ Nayan Ranjan Singha ${ }^{2} \cdot$ Subhasis Roy $^{1}$ (i)
}

Received: 27 June 2020 / Accepted: 18 November 2020 / Published online: 23 November 2020

(c) The Author(s) 2020

\begin{abstract}
This study reports the performance analysis of an organic dye-sensitized solar cell (DSSC), introducing $\mathrm{MnO}_{2}$ as an electron transport layer in $\mathrm{TiO}_{2} / \mathrm{MnO}_{2}$ bilayer assembly. The DSSCs have been fabricated using $\mathrm{TiO}_{2}$ and $\mathrm{TiO}_{2} / \mathrm{MnO}_{2}$ layer-by-layer architecture films onto fluorine-doped tin oxide (FTO) glass and sensitized with natural dye extracted from Malvaviscus penduliflorus flower in ethanol medium. The counter electrode was prepared to layer copper powder containing paste onto FTO's conductive side by the doctor's blade method. The optical, morphological, and structural properties of photoanodes were explored via ultraviolet-visible, field emission scanning electron microscopy, and X-ray diffraction analyses. Moreover, dye complexity and thermostability of dyes were characterized via Fourier-transform infrared spectroscopy and thermogravimetric analyses. The iodide/triiodide (i.e., $I^{-} / I_{3}^{-}$) redox couple of electrolyte solution was employed as a charge transport medium between the electrodes. Finally, photoanode and counter electrode sandwiches were assembled to envisage the photovoltaic performance potential under simulated AM $1.5 \mathrm{G}$ solar illumination using $100 \mathrm{~mW} \mathrm{~cm} \mathrm{c}^{-2}$ light intensity. The as-fabricated DSSC comprising $\mathrm{TiO}_{2} / \mathrm{MnO}_{2}$ bilayer assembly exhibited $6.02 \mathrm{~mA} \mathrm{~cm}{ }^{-2}$ short circuit current density $\left(J_{\mathrm{sc}}\right)$, $0.38 \mathrm{~V}$ open-circuit voltage $\left(V_{\mathrm{oc}}\right), 40.38 \%$ fill factor, and $0.92 \%$ conversion efficiency, which is about $200 \%$ higher compared to the assembly devoid of $\mathrm{MnO}_{2}$ layer.
\end{abstract}

Keywords Low cost dye-sensitized solar cells · Organic dye $\cdot$ Bilayer structure $\cdot$ Dye stability analysis

\section{Introduction}

Nowadays, clean, near-zero-emission and sustainable renewable energy production are vital concerns for policymakers worldwide. The energy consumption demand is expected to be doubled in 2050 [1, 2]. Notably, a significant percentage of energy demand is backed by fossil fuel-based resources, implying an adverse impact on global warming, environment, and ecosystem. For circumventing the problems related to the limited amount of fossil fuel and adverse

Subhasis Roy

srchemengg@caluniv.ac.in; subhasis1093@gmail.com

1 Department of Chemical Engineering, University of Calcutta, 92 APC Road, Kolkata, West Bengal 700009, India

2 Advanced Polymer Laboratory, Department of Polymer Science and Technology, Government College of Engineering and Leather Technology (Post Graduate), Maulana Abul Kalam Azad University of Technology, Salt Lake City, Kolkata, West Bengal 700106, India environmental concerns, present researchers are focused on renewable energy sources, i.e., solar energy, which is abundant and cost-effective.

Of variable third-generation solar cells, DSSC is low cost and easy to fabricate. The DSSC module works as a photoelectrochemical device in which electron-hole pair is generated via light-induced exciton [3]. The dye-anchored metal oxide semiconductor, i.e., $\mathrm{TiO}_{2}$, works as an electron transport layer, and electrolyte functions as a charge transport media and electron recombination suppression media between photoanode and cathode $[4,5]$.

The sensitizer mostly influences the performance potential of DSSC. The absorption of a wider range of light spectrum and a high molar absorption coefficient elevate the light-harvesting ability of $\mathrm{TiO}_{2}$ film. The natural color pigments of plant leaves, fruits, and flowers can be used as a sensitizer for DSSC application(s). Though DSSC has impressive performance under indoor lighting, the long-term stability and outdoor performance under high-temperature ambient conditions are yet to be achieved to date [6]. Moreover, the DSSC conversion efficiency is much lower than that 
of the commercially available silicon-based solar cells. The chlorophyll extract from various leaves has been used as a natural sensitizer in DSSC.

Moreover, in DSSC, red/purple pigment in various leaves/ flowers has been used as a sensitizer [7]. Notably, an abundantly available organic dye is easily extracted from flowers and leaves, mainly responsible for light absorption in DSSC. It is expected that the dye should absorb ultraviolet-visible (UV-Vis) and near-infrared (NIR) regions of the light spectrum. The hydrophobic organic dye is selected for long-term stability. Hydrophobic dye reduces the possibility of direct contact among photoanode and liquid electrolyte, retarding water-induced dye degradation for the cell's longterm stability $[8,9]$. The natural color pigments originated from organic dyes impart an anthocyanins group present in the different parts (e.g., flower, leaves) of the plant [10-12]. Red pigment-containing flower Hibiscus rosa-sinensis possessing a higher concentration of anthocyanins group is used for a natural dye-sensitized solar cell [13, 14]. In fact, Malvaviscus penduliflorus flower is closely related to the Hibiscus family. However, potential research based on $M$. penduliflorus flower -extracted dye in DSSC is still lacking. The broader absorption of Hibiscus-extracted dye within 400-500 nm can further be enhanced using either concentrated dye solution or operating the sensitization process at elevated temperature [15-17]. The absorption defect of the M. penduliflorus flower-extracted dye starts from $550 \mathrm{~nm}$ onward [18]. The performance of the DSSC can be compensated introducing a scattering layer or interfacial modification in the photoanode and concomitantly improves the broader spectrum wavelength range of light absorption to make it suitable for outdoor application(s) $[19,20]$. The front side and back side illumination for photovoltaic devices originate from the cost-effective perspective, as the higher percentage of the incident solar spectrum can be harvested without altering the cell area. The light-harvesting property, along with the back side illumination, of the device can be enhanced by integrating porous scattering sensitized film, i.e., mesoporous $\mathrm{TiO}_{2}$, with a semi-transparent counter electrode. $\mathrm{TiO}_{2}$ has a wide bandgap of around $3.2 \mathrm{eV}$ and is used widely in DSSC photoanode fabrication [21]. The tuning of optical and electrical properties and device performance enhancement is possible via suitable semiconductor material doping in the layered architecture [22, 23]. In this regard, semiconductor and bilayer assembly with $\mathrm{MnO}_{2} / \mathrm{TiO}_{2}$ can be employed for DSSC application(s).

Moreover, the bandgap of $\mathrm{MnO}_{2}$ around $2.57 \mathrm{eV}$ makes it an ideal material for $\mathrm{MnO}_{2} / \mathrm{TiO}_{2}$ bilayer photoanode fabrication [24]. In DSSC fabrication, most of the research works use expensive platinum as a counter electrode, limiting the employability toward large-scale production. Thus, less expensive copper as a counter electrode is expected to facilitate the large-scale industrial application(s). This research's main objective is to elevate the output performance of costfriendly DSSC by incorporating bilayer $\mathrm{TiO}_{2} / \mathrm{MnO}_{2}$ in the working electrode. Moreover, the present work aims to draw attractive attention toward cost effective DSSC fabrication. Accordingly, an attempt was made to extract the dye, i.e., sensitizer, from natural origin, i.e., Malvaviscus penduliflorus flower layer-by-layer architecture of $\mathrm{TiO}_{2} / \mathrm{MnO}_{2}$ toward the fabrication of photoelectrode for cost-friendly DSSC fabrication/ application.

\section{Experimental details}

\section{Materials and chemicals}

All the chemicals were purchased from commercial sources and used without purification. Natural dye was extracted from Malvaviscus penduliflorus flower using ethanol. Fluorine-doped tin oxide (FTO) glass substrate of 12-15 $\Omega \mathrm{sq}^{-1}$ surface resistivity and $2.3 \mathrm{~mm}$ thickness purchased from Pilkington (India) was used as a conductive surface in the working and counter electrodes. Scotch tape $(25 \mu \mathrm{m} \mathrm{mm}$ thick, Solaronix) was used in the doctor's blade method to control the film's thickness. $\mathrm{TiO}_{2}$ nanoparticle paste (Solaronix, $18 \mathrm{wt} \%$ ) was used for thin film deposition on the working electrode. The polyvinyl alcohol dhesive was used as a binder for preparing $\mathrm{MnO}_{2}$ powder paste and copper powder paste. $\mathrm{MnO}_{2}$ powder (Fisher Scientific, India) was used for bilayer assembly preparation in photoanode. Copper powder (Loba Chemie, India) was used to prepare a counter electrode with copper paste. Potassium iodide and iodine were used to prepare the iodide/ triiodide electrolyte solution and acted as a charge transport media between the two electrodes. Paraffin spacer (50 $\mu \mathrm{m}$ thick, Merck, Germany) was used as a sealant and separation layer between the two electrodes during device assembling.

\section{Cleaning of glass substrates}

FTO glass substrates were appropriately cleaned with distilled water, followed by ethanol in an ultrasonic bath for $10 \mathrm{~min}$ before the material deposition.

\section{Fabrication of working electrode}

A scotch tape of $25 \mu \mathrm{m}$ thickness was used to cover the cleaned FTO glass substrate's edges for making bottom contact. The thickness of $\mathrm{TiO}_{2}$ and $\mathrm{TiO}_{2} / \mathrm{MnO}_{2}$ bilayer photoanodes was controlled to approximately $25 \mu \mathrm{m}$ and $50 \mu \mathrm{m}$, respectively. A transparent $\mathrm{TiO}_{2}$ nanoparticle paste was layered on the FTO glass substrate's conductive side by the doctor blade method. The as-prepared $\mathrm{TiO}_{2}$ film was dried in a hot air oven dryer at $70{ }^{\circ} \mathrm{C}$ for 
approximately $15 \mathrm{~min}$ before $\mathrm{MnO}_{2}$ layer deposition. After that, $0.1 \mathrm{~g} \mathrm{MnO}_{2}$ powder was mixed with $1 \mathrm{~g}$ adhesive to prepare a uniformly dispersed $\mathrm{MnO}_{2}$ powder paste. $\mathrm{MnO}_{2}$ paste was similarly deposited onto the $\mathrm{TiO}_{2}$ layer, followed by drying at around $70{ }^{\circ} \mathrm{C}$ for $15 \mathrm{~min}$. The layerby-layer architecture deposition method was employed for $\mathrm{TiO}_{2} / \mathrm{MnO}_{2}$ bilayer assembly preparation. The thickness of the $\mathrm{TiO}_{2}$ and $\mathrm{TiO}_{2} / \mathrm{MnO}_{2}$ bilayer photoanodes was maintained at $25 \mu \mathrm{m}$ and $50 \mu \mathrm{m}$, respectively. Finally, $\mathrm{TiO}_{2}$ and $\mathrm{TiO}_{2} / \mathrm{MnO}_{2}$ bilayer structure samples were annealed in a furnace at $450{ }^{\circ} \mathrm{C}$ for $45 \mathrm{~min}$ to improve the deposited surface morphology and crystallinity material. The samples were cooled down slowly to avoid any surface defects or cracks before dipping the samples in a natural dye solution. These samples were immersed in a dye solution for $36 \mathrm{~h}$ and kept in a dark place at room temperature. The electrode samples were gently washed with distilled water to remove any unadsorbed excess dye and dried in a hot oven air dryer at $40{ }^{\circ} \mathrm{C}$ for $5 \mathrm{~min}$.

\section{Fabrication of the counter electrode}

Here, a cleaned FTO glass substrate was used for counter electrode fabrication. Scotch tape was used to cover the edges of the FTO glass, similar to working electrode preparation. $0.12 \mathrm{~g}$ copper powder was mixed with $1 \mathrm{~g}$ adhesive to prepare a uniformly dispersed copper powder paste. The as-prepared copper powder paste was deposited on the precleaned FTO glass's conductive side by the doctor blade method. Finally, the sample was placed in a furnace at around $200^{\circ} \mathrm{C}$ for $1 \mathrm{~h}$. Before removing the furnace sample, the copper-coated FTO counter electrode was cooled slowly to avoid any surface cracks on the thin film.

\section{Preparation of natural dye solution}

Herein, $5 \mathrm{~g}$ of fresh Malvaviscus penduliflorus flower (Fig. 1a) was washed with distilled water and cleaned flower petals were cut into small pieces. After that, the flower petals in $100 \mathrm{ml}$ ethanol were poured in a mixer and ground for $3 \mathrm{~min}$. The process was repeated thrice for preparing a thick solution. Furthermore, the solution was
Fig. 1 a Picture of Malvaviscus penduliflorus flower, b dye solution extracted from Malvaviscus penduliflorus flower, and $\mathbf{c}$ schematic of $\mathrm{TiO}_{2} / \mathrm{MnO}_{2}$ bilayerassembled solar cell
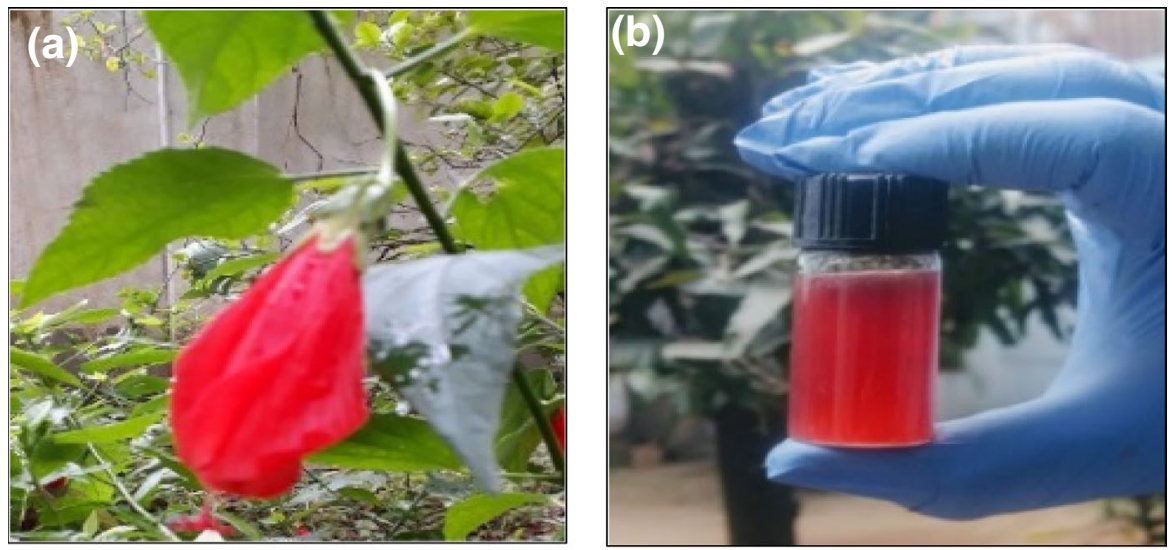

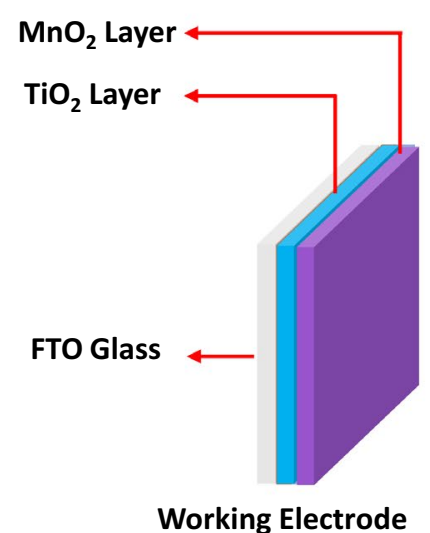

(c)

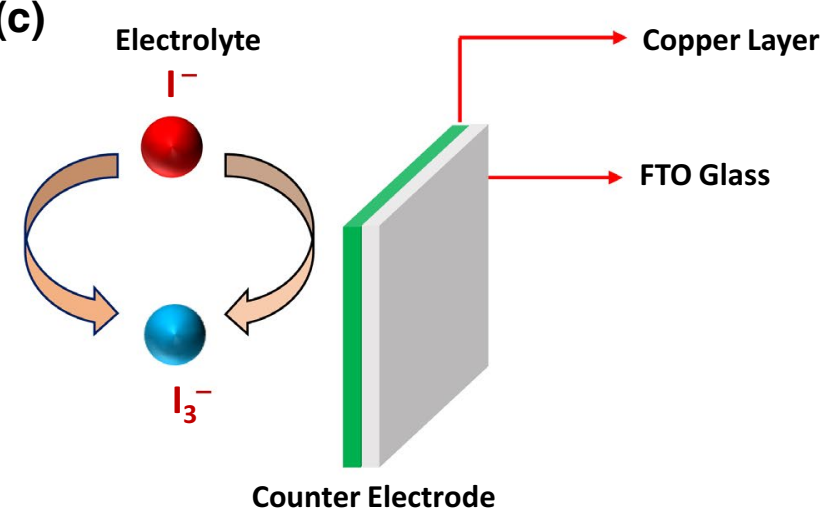

FTO Glass

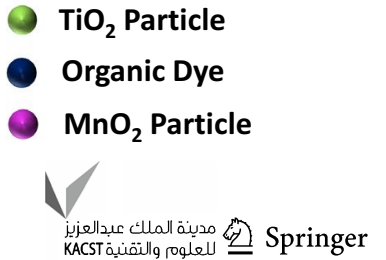


stirred continuously in a magnetic stirrer for $2 \mathrm{~h}$ to get a uniformly dispersed solution (Fig. 1b). The solution was kept in a cold and dark place for $36 \mathrm{~h}$ before filtration. Finally, the filtrate dye solution was collected and the residue was filtered out. The as-prepared dye solution, i.e., sensitizer, was safely stored in a cold and dark place.

\section{Preparation of electrolyte}

Herein, $80 \mathrm{mg}$ potassium iodide and $13 \mathrm{mg}$ iodine were mixed with ethanol in a culture tube and placed under continuous stirring for $5 \mathrm{~min}$. The electrolyte solution containing a culture tube was stored in a dark place.

\section{DSSC device assembling}

The photoanodes and the copper-coated counter electrode were separated by a paraffin spacer and clamped together, keeping both the conducting surface facing each other (Fig. 1c). An electrolyte solution containing $I^{-} / I_{3}{ }^{-}$was injected in the hollow spacer area between the working electrode and counter electrode before assembling. As the electrolyte solution spread over and covered the whole active area via capillary action, two binder clips were used to hold the sandwich-like assembly for further electrical characterization.

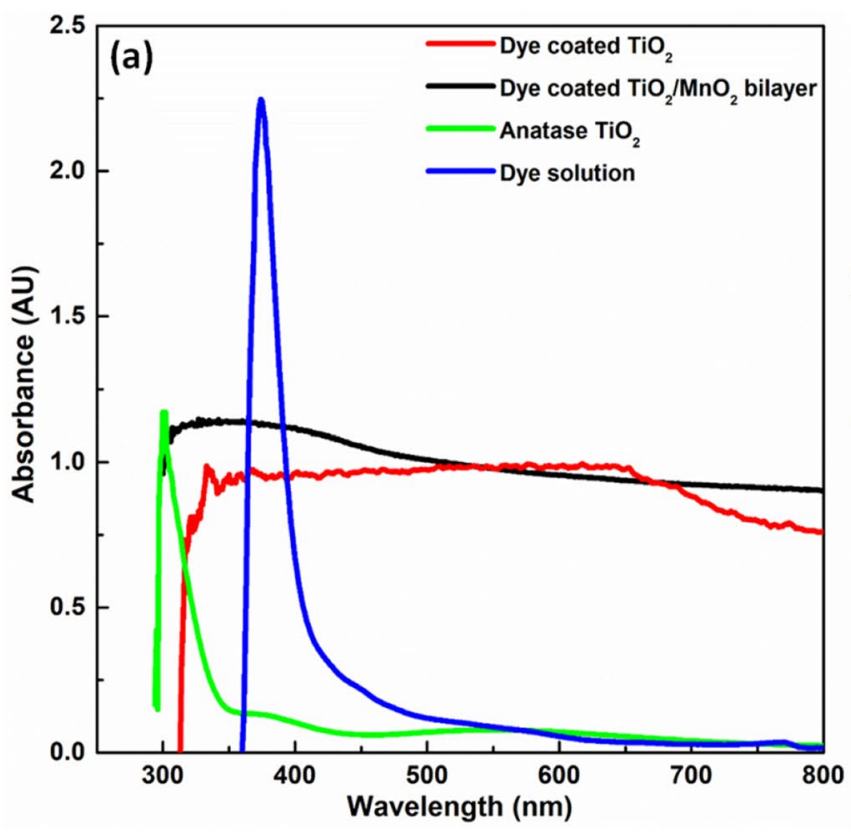

\section{Measurement and characterization}

The light absorption property of the dye solution, dyeadsorbed $\mathrm{TiO}_{2}$, and $\mathrm{TiO}_{2} / \mathrm{MnO}_{2}$ bilayer assembly of photoanode was analyzed and recorded using a UV-Vis spectrophotometer (Hitachi Spectrophotometer, Japan). In dye solutions, functionalities and complex molecular bindings were studied within $500-4000 \mathrm{~cm}^{-1}$ using Fourier transform infrared spectroscopy (PerkinElmer, USA). The nanostructure's surface topography on photoanode was investigated by field emission scanning electron microscopy (JEOL, Japan). The diffractogram was studied via XRD diffractometer (XPert PRO, USA) using a $\mathrm{CuK}_{\alpha}$ source (1.54 $\mathrm{A}$ ). $40 \mathrm{kV}$ and $30 \mathrm{~mA}$ sources were used to measure $2 \theta$ within $10^{\circ}-80^{\circ}$ using nickel-filtered $\mathrm{CuK}_{\alpha}$ radiation. The temperature-induced degradation of the natural dye material was characterized by TGA (PerkinElmer, USA). The fabricated DSSC performance was analyzed using an AM $1.5 \mathrm{G}$ sun simulator exhibiting irradiation of $100 \mathrm{~mW} \mathrm{~cm}{ }^{-2}$ intensity of light (Compact 150WSolar Simulator, Zolix Instruments, China) using source meter (model: 2450, Keithley, USA).

\section{Results and discussion}

\section{UV-Vis analysis}

Figure 2 envisages the absorption spectra of thin both films of natural dy-coated $\mathrm{TiO}_{2} / \mathrm{MnO}_{2}$ bilayer assembly,

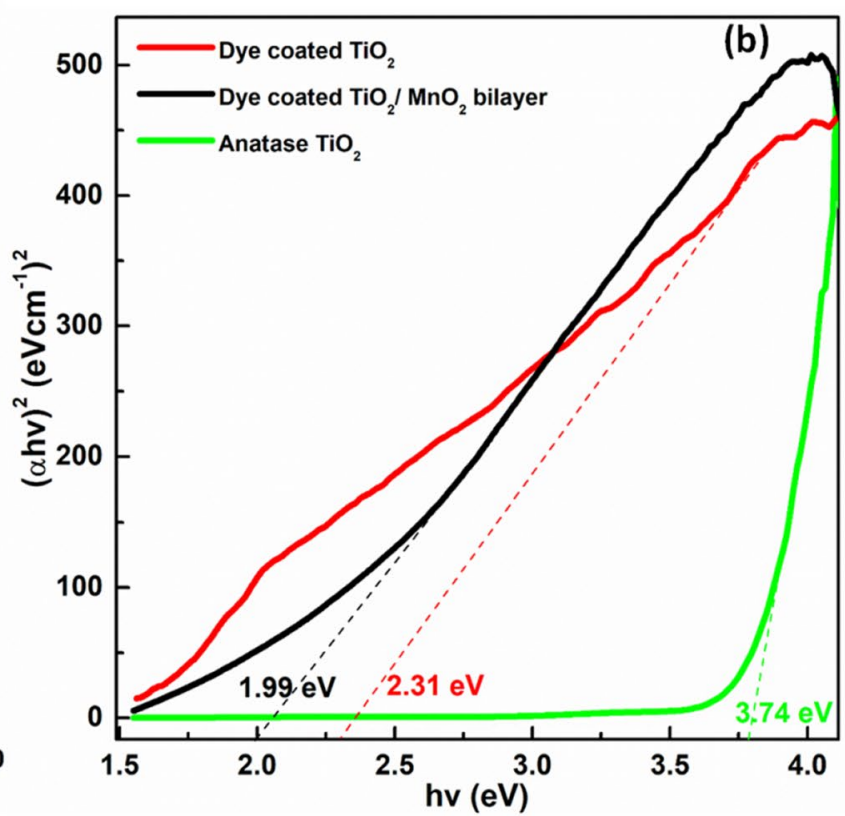

Fig. 2 a Optical absorption spectra of dye-coated $\mathrm{TiO}_{2} / \mathrm{MnO}_{2}$ bilayer, dye-coated $\mathrm{TiO}_{2}$, anatase $\mathrm{TiO}_{2}$, and dye solution and $\mathbf{b}$ extrapolation of the Tauc plot for bandgap calculation 
dye-coated $\mathrm{TiO}_{2}$, anatase $\mathrm{TiO}_{2}$, and dye solution. Though absorption band edges of $\mathrm{TiO}_{2}$ thin film and dye solution were observed at $300 \mathrm{~nm}$ and $375 \mathrm{~nm}$, respectively, no significant peak was found for $\mathrm{TiO}_{2} / \mathrm{MnO}_{2}$ bilayer assembly and dye-coated $\mathrm{TiO}_{2}$. Interestingly, $\mathrm{TiO}_{2} / \mathrm{MnO}_{2}$ bilayer assembly and dye-coated $\mathrm{TiO}_{2}$ envisaged higher absorbance and long UV-Vis spectrum than the rest of the samples. From the Tauc plot, anatase $\mathrm{TiO}_{2}$ envisaged a high bandgap of $3.74 \mathrm{eV}$, whereas dye-coated $\mathrm{TiO}_{2}$ and $\mathrm{TiO}_{2} / \mathrm{MnO}_{2}$ bilayer assembly presented 2.31 and $1.99 \mathrm{eV}$ bandgaps, respectively. Thus, the photoanode fabricated with dye-coated $\mathrm{TiO}_{2} / \mathrm{MnO}_{2}$ bilayer assembly elevated the absorption property throughout the longer UV-Vis spectrum via layer-by-layer photoanode architecture fabrication, suitable for solar cell application [25].

\section{FTIR analysis}

The Fourier-transform infrared spectroscopy (FTIR) peak at $3418 \mathrm{~cm}^{-1}$ was ascribed to the $\mathrm{O}-\mathrm{H}$ str. of dye [26]. Moreover, peaks at 2925 and $2864 \mathrm{~cm}^{-1}$ were related to the C-H str. of $-\mathrm{CH}_{2}-$ and $-\mathrm{CH}_{3}$ functionalities, respectively [27]. The $-\mathrm{C} \equiv \mathrm{N}, \mathrm{C}-\mathrm{N}$ and $\mathrm{N}-\mathrm{H}$ str. of amide, $-\mathrm{CH}_{3}$, and $-\mathrm{O}-\mathrm{C} \equiv \mathrm{N}$ functionalities in dye were confirmed from peaks at $2088,1633,1385$, and $1085 \mathrm{~cm}^{-1}$, respectively [28, 29]. In $\mathrm{ETOH}$, the change in $\mathrm{C}-\mathrm{O}$ str' intensity was substantiated via slight displacement of the peak from 1094 to $1085 \mathrm{~cm}^{-1}$ in ethanol-dye solution (see Fig. 3).

\section{FESEM analysis}

Field emission scanning electron microscopy (FESEM) images envisaged uniform particle size distribution of
Fig. 3 FTIR spectra of $99.9 \%$ ethanol and Malvaviscus penduliflorus flower-extracted dye in ethanol solution

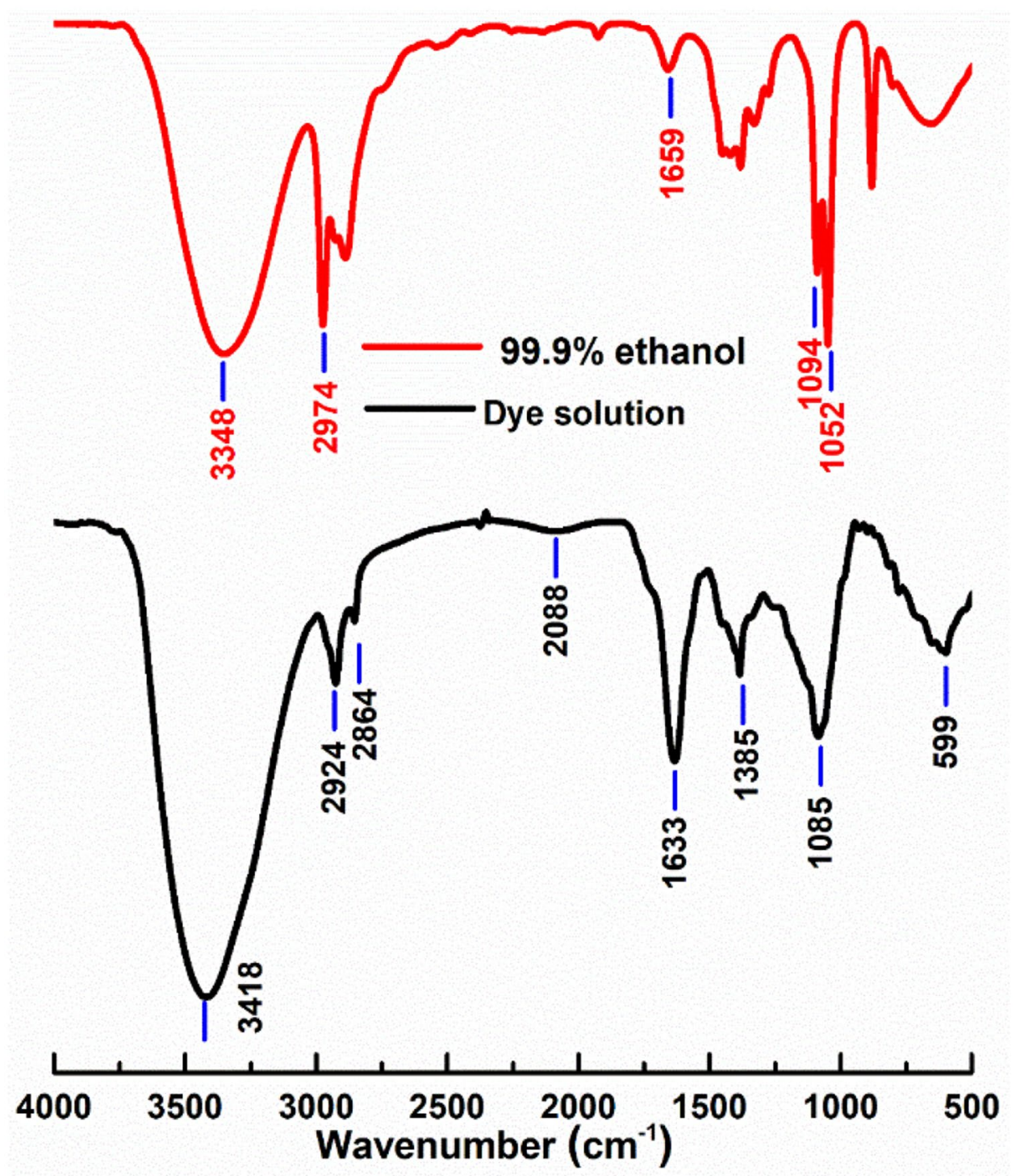


$\mathrm{TiO}_{2}$ within $20-40 \mathrm{~nm}$ and resembled a distributed porous nanostructure network. $\mathrm{TiO}_{2} / \mathrm{MnO}_{2}$ bilayer nanostructure was more compact than $\mathrm{TiO}_{2}$. The surface morphology altered from the granular porous network of $\mathrm{TiO}_{2}$ to a more compact and relatively larger grain size of $\mathrm{MnO}_{2}$ in the $\mathrm{TiO}_{2} / \mathrm{MnO}_{2}$ bilayer assembly. The incorporation of $\mathrm{MnO}_{2}$ in a bilayer assembly significantly reduced the void fractions in the photoanode sample. The larger surface area of layer-by-layer architecture of $\mathrm{TiO}_{2} / \mathrm{MnO}_{2}$ bilayer assembly compared to other photoanode counterparts resulted in higher dye loading capability in the nanostructure [30]. The surface roughness and void fractions on the photoanode samples should substantially impact the electrical performances of the photoanode [31]. In this regard, the nanomaterials' electrical performance is significantly influenced via surface morphology linked directly with the specific surface area interaction with electrolyte [32] (see Fig. 4).
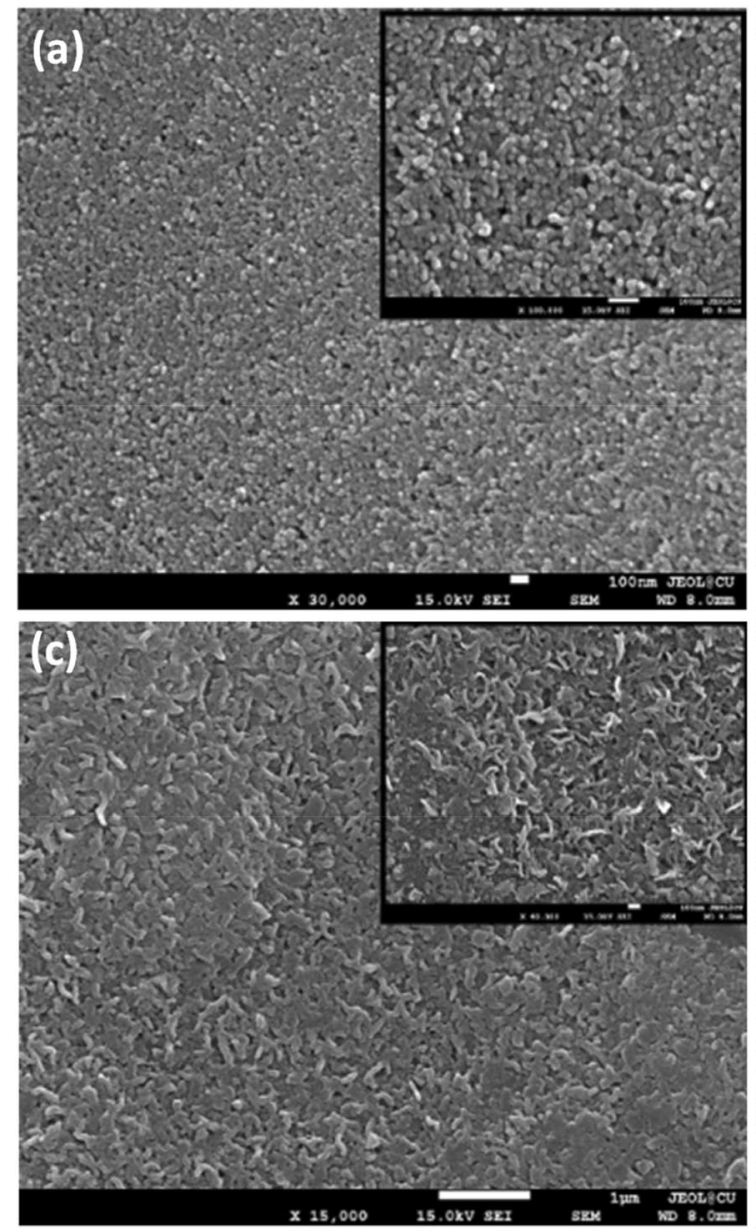

Fig. 4 FESEM images of a $\mathrm{TiO}_{2}$ photoanode, $\mathbf{b}$ particle diameter and pore size in $\mathrm{TiO}_{2}$ sample, $\mathbf{c} \mathrm{TiO}_{2} / \mathrm{MnO}_{2}$ bilayer photoanode, and $\mathbf{d} \mathrm{MnO} 2$ particle size

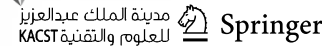
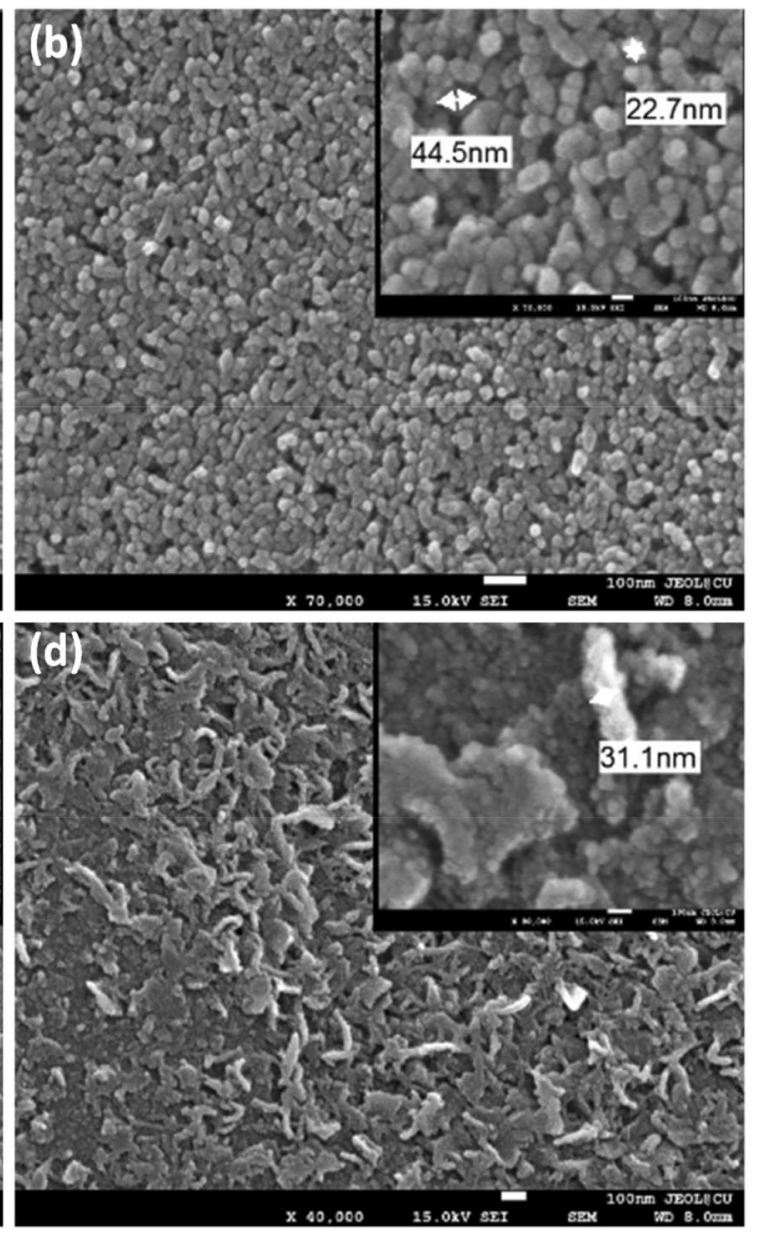

\section{Structural analysis}

The extent of orderliness, i.e., crystalline nature, and phase formation of the dye-adsorbed $\mathrm{TiO}_{2} / \mathrm{MnO}_{2}$ bilayer photoanode and $\mathrm{TiO}_{2}$ film were characterized by thin film XRD analysis (Fig. 5) in which the characteristic diffraction peaks recorded at $2 \theta=25.78^{\circ}, 37.6^{\circ}, 38.18^{\circ}, 48.38^{\circ}$, $54.37^{\circ}, 63.22^{\circ}$, and $69.21^{\circ}$ corresponding to crystallographic planes (101), (103), (004), (200), (105), (204), and (541) of the anatase phase of $\mathrm{TiO}_{2}$, respectively [33]. The complexation among $\mathrm{TiO}_{2}$ and $\mathrm{MnO}_{2}$ was substantiated by the presence of $\mathrm{MnTiO}_{3}$ in bilayer structure photoanode [34], confirmed by the diffraction peaks of $\mathrm{MnTiO}_{3}$ at $2 \theta=31.64^{\circ}, 35.34^{\circ}, 51.8^{\circ}$, and $60.47^{\circ}$ for (104), (110), (116), and (124) crystallographic planes, respectively. Moreover, the peaks at $2 \theta=28.35^{\circ}, 37.55^{\circ}, 60.59^{\circ}$, and $65.86^{\circ}$ for $(310),(211),(521)$, and (002) planes confirmed the presence of $\mathrm{MnO}_{2}$ [35]. The additional characteristic peaks were correlated to the prevalent FTO and Ti [36]. In the $\mathrm{TiO}_{2} / \mathrm{MnO}_{2}$ bilayer assembly, a slight change in the 
Fig. 5 XRD pattern of $\mathrm{TiO}_{2}$ and $\mathrm{TiO}_{2} / \mathrm{MnO}_{2}$ bilayer films

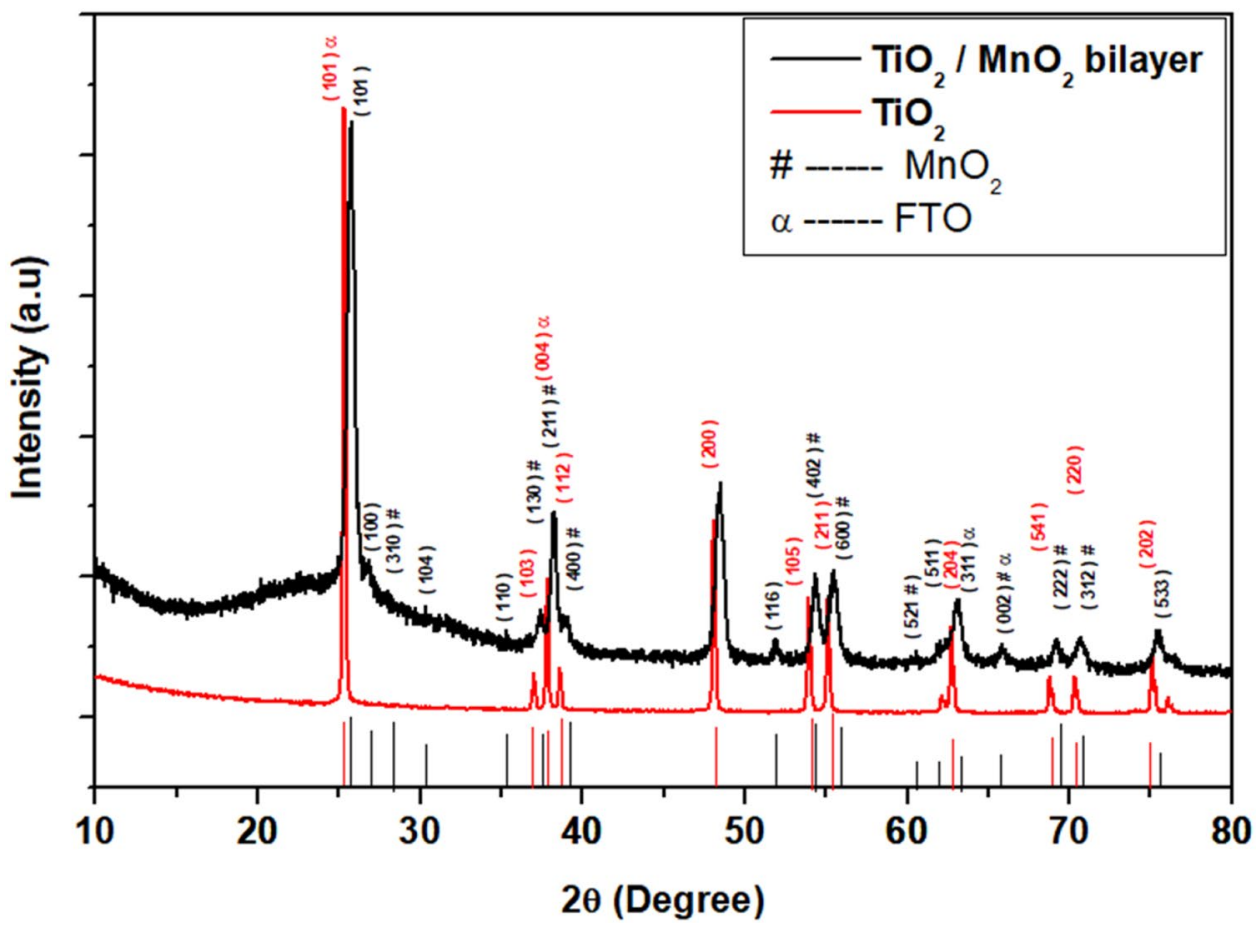

main peak position of $\mathrm{TiO}_{2}$ from $25.32^{\circ}$ to $25.78^{\circ}$ was ascribed to the change in $\mathrm{TiO}_{2}$ crystal lattice due to the diffusion of $\mathrm{Mn}^{2+}$ ion in the $\mathrm{TiO}_{2}$ crystal.

\section{TG analysis}

Figure 6 shows the differential thermal analysis (DTA), derivative thermogravimetry (DTG) and TG curves of the natural dye extracts of Malvaviscus penduliflorus flower. From the dye's TG curve (Fig. 6), the weight losses within
Fig. 6 TG analysis of Malvaviscus penduliflorus flower extract

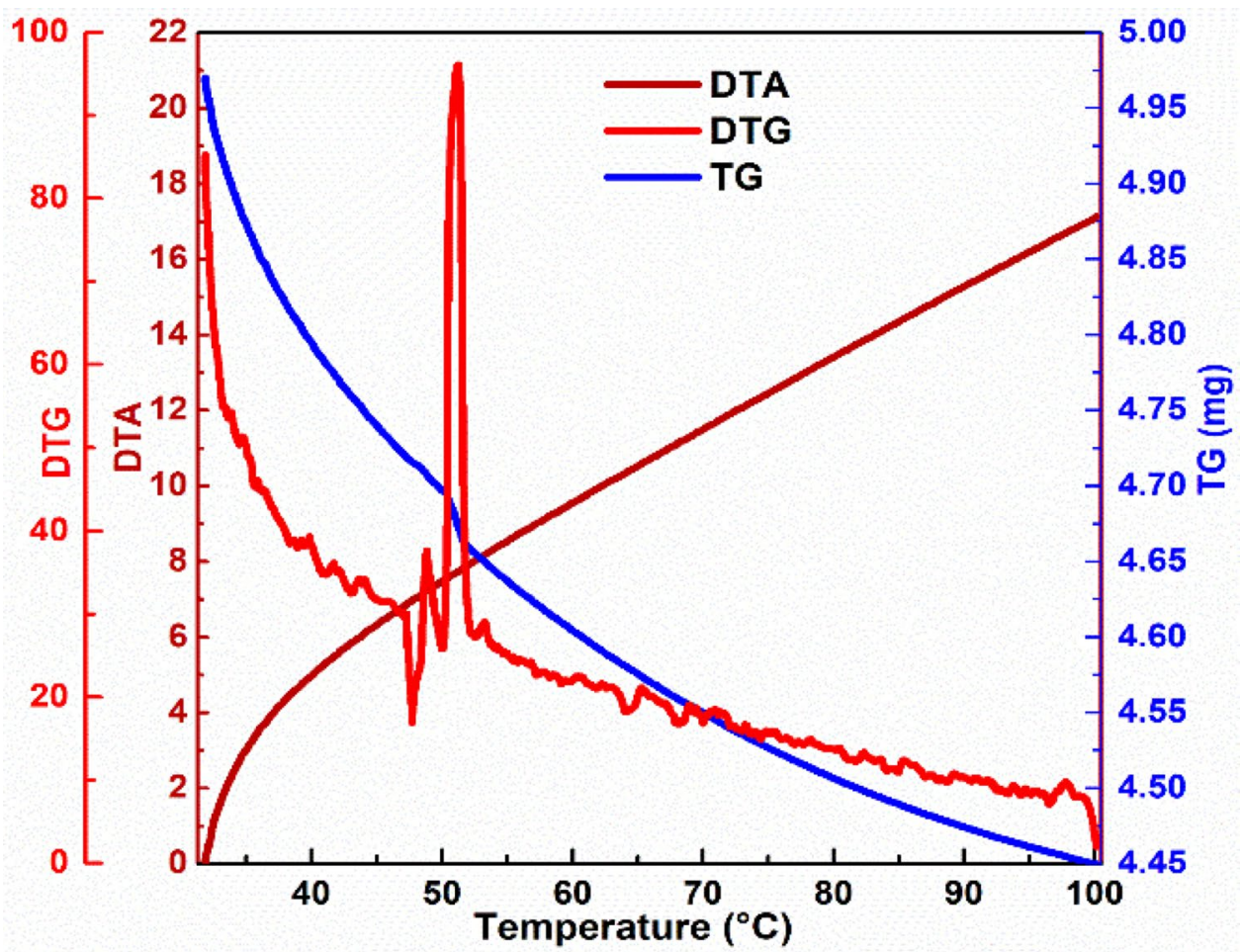


50-100 ${ }^{\circ} \mathrm{C}$ corresponded to the loss of unbound water in the dye. Notably, the DTA curve was devoid of exothermic decomposition peak(s) or the endothermic dehydration peak(s) within $50-100{ }^{\circ} \mathrm{C}$. Thus, this dye was suitable for DSSC solar cell application(s), confirming the dye's suitability in extreme climate conditions [6].

\section{Photovoltaic study}

The photovoltaic characteristics of the natural dye-sensitized DSSCs were tested via current density-voltage $(J-V)$ and power-voltage $(P-V)$ measurements. $\mathrm{TiO}_{2}$ and $\mathrm{TiO}_{2} / \mathrm{MnO}_{2}$ bilayer-assembled DSSCs were tested under simulated AM $1.5 \mathrm{G}$ solar illumination having $100 \mathrm{~mW} \mathrm{~cm} \mathrm{~cm}^{-2}$ light intensity. The performance was measured using a Keithley source meter at $27{ }^{\circ} \mathrm{C}$. The output result of photovoltaic performance and different parameters of DSSCs, i.e., open-circuit voltage $\left(V_{\mathrm{oc}}\right)$, short circuit current density $\left(J_{\mathrm{sc}}\right)$, fill factor (FF), efficiency $(\eta)$, and maximum power output $\left(P_{\max }\right)$, are given in Table 1. Because of the higher dye loading in $\mathrm{TiO}_{2} / \mathrm{MnO}_{2}$ bilayer nanostructure, the dye-adsorbed $\mathrm{TiO}_{2} /$ $\mathrm{MnO}_{2}$ bilayer assembly showed more conversion efficiency compared to that of $\mathrm{TiO}_{2}$ in the photoanode (Fig. 7) [37]. Indeed, the bilayer assembly imparted an additional surface area for a higher amount of dye loading [38]. The decrease in open-circuit voltage $\left(V_{\text {oc }}\right)$ in the bilayer assembly could be attributed to the nanoparticles' elevated interfacial resistance. The Jsc improved significantly in the bilayer assembly due to increased spectral response with a longer wavelength. Interestingly, for both the photoanode samples, an increase in $V_{\mathrm{oc}}$ and a decrease in $J_{\mathrm{sc}}$ were noted in the back side illumination. The rise in $V_{\text {oc }}$ was ascribed to the slow electron recombination, whereas the decrease in $J_{\mathrm{sc}}$ was related to reducing light penetration intensity in the back

Table 1 Photovoltaic parameters of $\mathrm{TiO}_{2}$ and $\mathrm{TiO}_{2} / \mathrm{MnO}_{2}$ bilayer DSSC cells (active area of cell was $1 \mathrm{~cm}^{2}$ )

\begin{tabular}{|c|c|c|c|c|c|c|}
\hline & Materials for photoanode & $V_{\mathrm{oc}}(\mathrm{V})$ & $J_{\mathrm{sc}}\left(\mathrm{mA} \mathrm{cm}^{-2}\right)$ & $\mathrm{FF}(\%)$ & PCE $(\%)$ & $P_{\max }(\mathrm{mW})$ \\
\hline \multirow[t]{2}{*}{ Front side illumination } & Dye-adsorbed $\mathrm{TiO}_{2}$ & 0.24 & 2.50 & 52.20 & 0.31 & 0.31 \\
\hline & Dye-adsorbed $\mathrm{TiO}_{2} / \mathrm{MnO}_{2}$ bilayer & 0.23 & 7.00 & 54.70 & 0.88 & 0.88 \\
\hline \multirow[t]{2}{*}{ Back side illumination } & Dye-adsorbed $\mathrm{TiO}_{2}$ & 0.40 & 2.00 & 41.10 & 0.32 & 0.32 \\
\hline & Dye-adsorbed $\mathrm{TiO}_{2} / \mathrm{MnO}_{2}$ bilayer & 0.38 & 6.02 & 40.30 & 0.92 & 0.92 \\
\hline
\end{tabular}

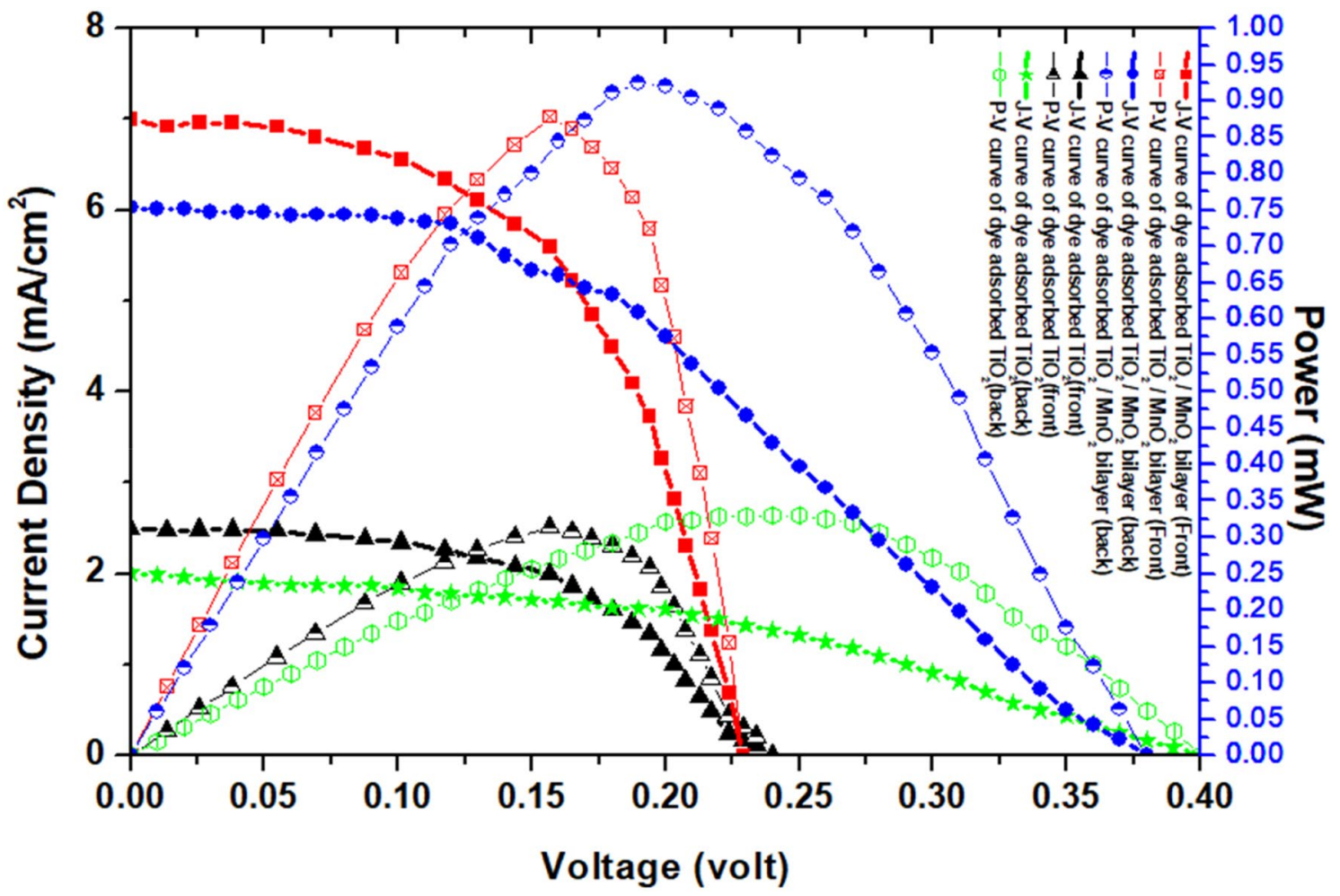

Fig. 7 Current density-voltage $(J-V)$ and power voltage $(P-V)$ plots of $\mathrm{TiO}_{2}$ and $\mathrm{TiO}_{2} / \mathrm{MnO}_{2}$ bilayer solar cells 
side illumination direction [39]. Notably, both light scattering effects and light reabsorbing ability of dye molecule reduced in the back side illumination.

The recombination kinetics of dye-coated $\mathrm{TiO}_{2}$, and $\mathrm{TiO}_{2} /$ $\mathrm{MnO}_{2}$ bilayer-assembled DSSC devices were analyzed using open-circuit voltage decay (OCVD) studies. From the asobtained OCVD curve (Fig. 8), the lifetime of $V_{\text {oc }}$ prevailed in the region between steady state and dark equilibrium. Moreover, the devices' OCVD profiles presented a slow decay rate for dye-coated $\mathrm{TiO}_{2} / \mathrm{MnO}_{2}$ bilayer devices compared to the device devoid of bilayer assembly, confirming a slow recombination rate in the bilayer structure of the device. Herein, the lifetime of the charge carrier is influenced by photoanode hierarchical architecture [40]. Notably, the lifetime of the charge carrier and $V_{\text {oc }}$ decay were correlated by the following reported equation [41]:

$\tau=\frac{k T}{e}\left(\frac{\mathrm{d} V_{\mathrm{oc}}}{\mathrm{d} t}\right)^{-1}$,
Here, $k, T$, and $e$ represent Boltzmann constant, absolute temperature, and charge of electron, respectively. The bilayer structure photoanode envisaged a slower slope than the device without bilayer, supporting a slower recombination rate and longer lifetime of charge carrier (see Table 2).

\section{Conclusions}

Natural dye extract from Malvaviscus penduliflorus flower has been used for the fabrication of low-cost and ecofriendly DSSCs. The dye molecule's adsorption in the $\mathrm{TiO}_{2}$ matrix facilitates the charge transfer from the dye molecule to the $\mathrm{TiO}_{2}$ conduction band, elevating the efficiency. $\mathrm{MnO}_{2}$ in the $\mathrm{TiO}_{2} / \mathrm{MnO}_{2}$ bilayer structure reduces the bandgap, improving DSSC performance. The FTIR result indicates the interaction of dye molecule with alcohol. The change in intensity and shift of the peaks have revealed a chargetransfer complex between the dye molecule and alcohol. The hydroxyl anchored group's presence in the dye solution improves the light absorption coefficient in the visible
Fig. 8 Open circuit voltage decay of $\mathrm{TiO}_{2}$ and $\mathrm{TiO}_{2} / \mathrm{MnO}_{2}$ bilayer DSSC in the dark after an illumination period of $3 \mathrm{~s}$ at AM1.5 G
Table 2 Lifetime of the charge carrier in $\mathrm{TiO}_{2}$ and $\mathrm{TiO}_{2} / \mathrm{MnO}_{2}$ bilayer DSSC cells

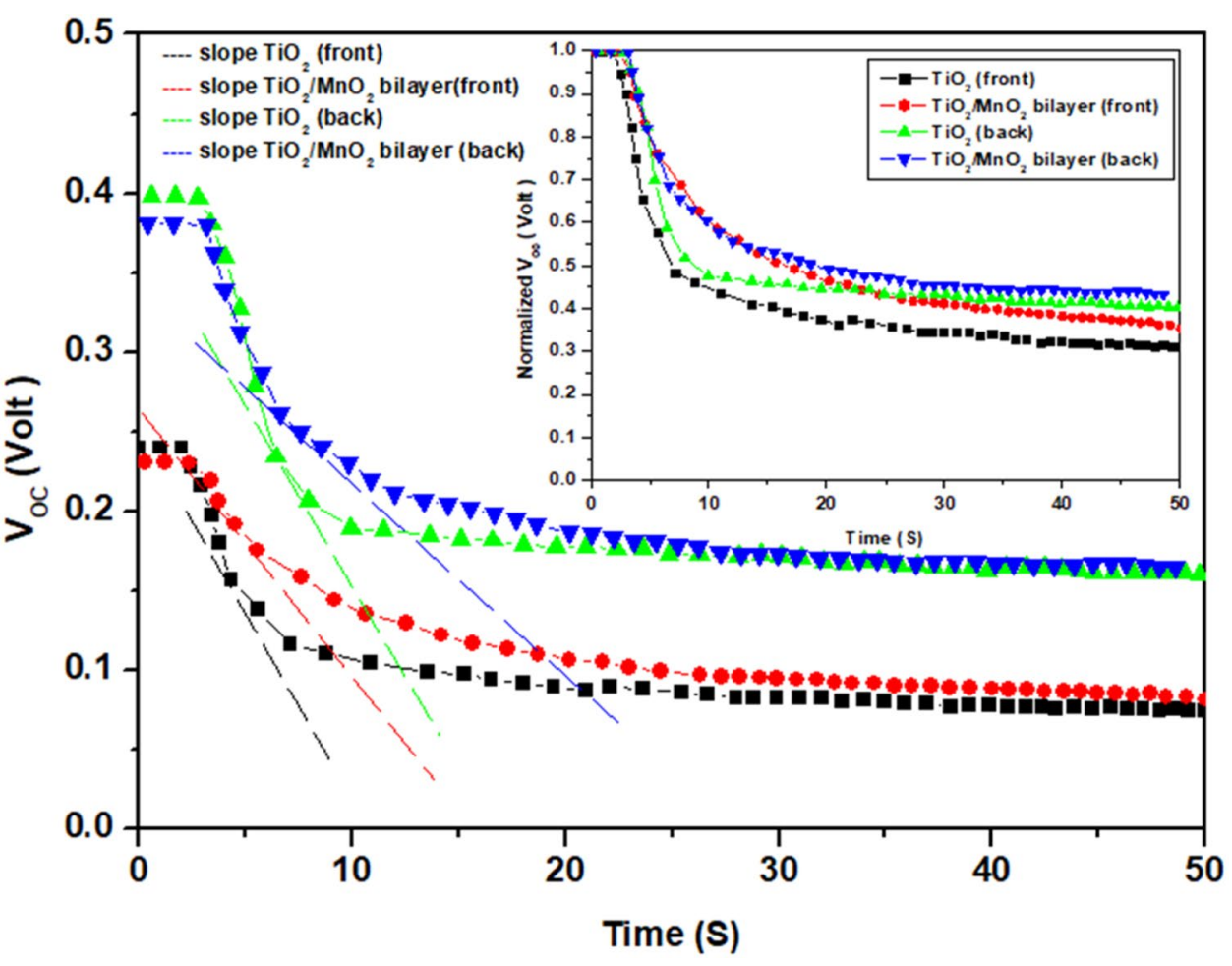

\begin{tabular}{lll}
\hline & Photoanode materials & Lifetime/( $(\mathrm{s}))$ \\
\hline Front side illumination & Dye-adsorbed $\mathrm{TiO}_{2}$ & 0.289 \\
& Dye-adsorbed $\mathrm{TiO}_{2} / \mathrm{MnO}_{2}$ bilayer & 0.344 \\
Back side illumination & Dye-adsorbed $\mathrm{TiO}_{2}$ & 0.320 \\
& Dye-adsorbed $\mathrm{TiO}_{2} / \mathrm{MnO}_{2}$ bilayer & 0.560 \\
\hline
\end{tabular}


spectrum. FESEM images of bilayer structure photoanode comprise the maximum surface coverage with the minimum agglomeration and void portion. Incorporating the $\mathrm{MnO}_{2}$ layer works as an interface between the $\mathrm{TiO}_{2}$ and electrolyte layer, which improves the surface passivation and electron transport. The deposition of the $\mathrm{MnO}_{2}$ layer on the $\mathrm{TiO}_{2}$ photoanode has no significant impact on the phase change of the $\mathrm{TiO}_{2}$ material. Thus, the interaction between $\mathrm{TiO}_{2}$ and $\mathrm{MnO}_{2}$ layer has effects only on the surroundings optoelectronic change. It was evident that the minor shift of the main $\mathrm{TiO}_{2}$ peak position at a higher diffraction angle can be attributed to incorporating $\mathrm{Mn}^{2+}$ ion into the $\mathrm{TiO}_{2}$ lattice. TG analysis confirmed the thermostability of dye up to $100^{\circ} \mathrm{C}$. Combining an electron transport layer like $\mathrm{MnO}_{2}$ on $\mathrm{TiO}_{2}$ material significantly improves the optoelectronic property of the photoanode. It is also concluded that incorporating an electron transport layer like $\mathrm{MnO}_{2}$ on $\mathrm{TiO}_{2}$ material significantly improves the optoelectronic property of the photoanode due to a combination of several factors including the increase of dye absorption. The significant improvement of quality charge extraction increases the diffusional length of charge carriers and reduces surface recombination enhanced the performance of the DSSC.

Acknowledgements This work was supported by Science and Engineering Research Board (SERB) grants funded by Department of Science and Technology (DST) Central, Government of India through Teachers Associateship for Research Excellence (TAR/2018/000195) [S. Roy]. The authors would like to acknowledge Dr. Achintya Singha, Associate Professor, Department of Physics Main Campus Bose Institute Kolkata for his valuable comments and ideas which helped to improve the manuscript.

\section{Compliance with ethical standards}

Conflicts of interest There are no conflicts to declare.

Open Access This article is licensed under a Creative Commons Attribution 4.0 International License, which permits use, sharing, adaptation, distribution and reproduction in any medium or format, as long as you give appropriate credit to the original author(s) and the source, provide a link to the Creative Commons licence, and indicate if changes were made. The images or other third party material in this article are included in the article's Creative Commons licence, unless indicated otherwise in a credit line to the material. If material is not included in the article's Creative Commons licence and your intended use is not permitted by statutory regulation or exceeds the permitted use, you will need to obtain permission directly from the copyright holder. To view a copy of this licence, visit http://creativecommons.org/licenses/by/4.0/.

\section{References}

1. Caspeta, L., Buijs, N.A., Nielsen, J.: The role of biofuels in the future energy supply. Energy Environ. Sci. 6, 4 (2013)
2. Dey, A., Dhar, A., Roy, S., Das, B.C.: Combined organic-perovskite solar cell fabrication as conventional energy substitute. Mater. Today Proc. 4, 14 (2017)

3. Calogero, G., Bartolotta, A., Di Marco, G., Di Carlo, A., Bonaccorso, F.: Vegetable-based dye-sensitized solar cells. Chem. Soc. Rev. 44, 10 (2015)

4. Gu, S., Bi, E., Fu, B., Dodbiba, G., Fujita, T., Wilkinson, D.P., Wei, Y., Fang, B.: A circulating electrolyte for a high performance carbon-based dye-sensitized solar cell. Chem. Commun. 53, 40 (2017) ((Chem. Commun., 2017,53, 5561-5564))

5. Roy, S., Han, G.S., Shin, H., Lee, J.W., Mun, J., Shin, H., Jung, H.S.: Low temperature synthesis of rutile $\mathrm{TiO}_{2}$ Nanocrystals and their photovoltaic and photocatalytic properties. J. Nanosci. Nanotechnol. 15, 6 (2015)

6. Fakharuddin, A., Jose, R., Brown, T.M., Fabregat-Santiago, F., Bisquert, J.: A perspective on the production of dye-sensitized solar modules. Energy Environ. Sci 7, 12 (2014)

7. Calogero, G., Di Marco, G., Caramori, S., Cazzanti, S., Argazzi, R., Bignozzi, C.A.: Natural dye senstizers for photoelectrochemical cells. Energy Environ. Sci. 2, 11 (2009)

8. Bella, F., Gerbaldi, C., Barolo, C., Grätzel, M.: Aqueous dyesensitized solar cells. Chem. Soc. Rev. 44, 11 (2015)

9. Benesperi, I., Michaels, H., Freitag, M.: The researcher's guide to solid-state dye-sensitized solar cells. J. Mater. Chem. C 6, 44 (2018)

10. Khoo, H.E., Azlan, A., Tang, S.T., Lim, S.M.: Anthocyanidins and anthocyanins: colored pigments as food, pharmaceutical ingredients, and the potential health benefits. Food Nutr. Res. 61, 1 (2017)

11. Harborne, J.B., Williams, C.A.: Anthocyanins and other flavonoids (January 1998 to December 2000). Nat. Prod. Rep. 18, 3 (2001)

12. Trouillas, P., Sancho-García, J.C., De Freitas, V., Gierschner, J., Otyepka, M., Dangles, O.: Stabilizing and modulating color by copigmentation: Insights from theory and experiment. Chem. Rev. 116, 9 (2016)

13. Mak, Y.W., Chuah, L.O., Ahmad, R., Bhat, R.: Antioxidant and antibacterial activities of hibiscus (Hibiscus Rosa-sinensis L.) and cassia (Senna bicapsularis L.) flower extracts. J. King Saud Univ. Sci. 25, 4 (2013)

14. Zhang, J., Celli, G.B., Brooks, M.S.: Chapter 1. Natural sources of anthocyanins. Food Chem. Funct. Anal. 1, 33 (2019)

15. Tractz, G., Viomar, A., Dias, B., De Lima, C., Banczek, E., Da Cunha, M., Antunes, S., Rodrigues, P.: Recombination study of dye sensitized solar cells with natural extracts. J. Braz. Chem. Soc. 30, 371-378 (2018)

16. Moyez, S.A., Roy, S.: Dual-step thermal engineering technique : A new approach for fabrication of e ffi cient $\mathrm{CH} 3 \mathrm{NH} 3 \mathrm{PbI} 3$-based perovskite solar cell in open air condition. Sol. Energy Mater. Sol. Cells. 185, 145 (2018)

17. Soto-Robles, C., Luque, P., Gómez-Gutiérrez, C., Nava, O., Vilchis-Nestor, A., Lugo-Medina, E., Ranjithkumar, R., CastroBeltrán, A.: Study on the effect of the concentration of Hibiscus sabdariffa extract on the green synthesis of $\mathrm{ZnO}$ nanoparticles. Results in Physics 15, 102807 (2019)

18. Gottsberger, G.: Colour change of petals in Malvaviscus arboreus flowers. Acta Botan. Neerl. 20, 4 (1971)

19. Shah, M.F., Mirloup, A., Chowdhury, T.H., Sutter, A., Hanbazazah, A.S., Ahmed, A., Lee, J., Abdel-Shakour, M., Leclerc, N., Kaneko, R., Islam, A.: Cross-conjugated BODIPY pigment for highly efficient dye sensitized solar cells. Sustain. Energy Fuels 4, 4 (2020)

20. Dessì, A., Calamante, M., Sinicropi, A., Parisi, M.L., Vesce, L., Mariani, P., Taheri, B., Ciocca, M., Di Carlo, A., Zani, L., Mordini, A., Reginato, G.: Thiazolo[5,4-d]thiazole-based organic sensitizers with improved spectral properties for application in 
greenhouse-integrated dye-sensitized solar cells. Sustain. Energy Fuels 4, 5 (2020)

21. Aronne, A., Fantauzzi, M., Imparato, C., Atzei, D., De Stefano, L., D’Errico, G., Sannino, F., Rea, I., Pirozzi, D., Elsener, B., Pernice, P., Rossi, A.: Electronic properties of $\mathrm{Tio}_{2}$-based materials characterized by high $\mathrm{Ti}^{3+}$ self-doping and low recombination rate of electron-hole pairs. RSC Adv. 7, 4 (2017)

22. Kaphle, A., Echeverria, E., Mcllroy, D.N., Hari, P.: Enhancement in the performance of nanostructured cuo-zno solar cells by band alignment. RSC Adv. 10, 13 (2020)

23. Roy, S., Botte, G.G.: Perovskite solar cell for photocatalytic water splitting with a $\mathrm{TiO} 2 / \mathrm{Co}$-doped hematite electron transport bilayer. RSC Adv. 8, 5388 (2018)

24. Li, T., Wu, J., Xiao, X., Zhang, B., Hu, Z., Zhou, J., Yang, P., Chen, X., Wang, B., Huang, L.: Band gap engineering of MnO2 through in situ Al-doping for applicable pseudocapacitors. RSC Adv. 6, 17 (2016)

25. Tang, S., Qiu, W., Xiao, S., Tong, Y., Yang, S.: Harnessing hierarchical architectures to trap light for efficient photoelectrochemical cells. Energy Environ. Sci. 13, 3 (2020)

26. Shah, S., Biswas, R., Koschny, T., Dalal, V.: Unusual infrared absorption increases in photo-degraded organic films. Nanoscale 9, 25 (2017)

27. Lubezky, A., Chechelnitsky, L., Folman, M.: Ir spectra of $\mathrm{CH}_{4}$, $\mathrm{cd}_{4}, \mathrm{c}_{2} \mathrm{~h}_{4}, \mathrm{C}_{2} \mathrm{H}_{2}, \mathrm{CH}_{3} \mathrm{OH}$ and $\mathrm{CH}_{3} \mathrm{OD}$ adsorbed on $\mathrm{C} 60$ films. J. Chem. Soc., Faraday Trans. 92, 12 (1996)

28. Liao, L., Lien, C., Shieh, D., Chen, F., Lin, J.: FTIR study of adsorption and photochemistry of amide on powdered $\mathrm{TiO}_{2}$ : comparison of benzamide with acetamide. Phys. Chem. Chem. Phys. 4, 18 (2002)

29. Allwar, A.: Characteristics of pore structures and surface chemistry of activated carbons by physisorption, Ftir and Boehm methods. IOSR J. Appl. Chem. 2, 1 (2012)

30. Chen, B., Doucette, G., Priya, S.: Improved performance of flexible dye-sensitized solar cells based on hierarchical $\mathrm{TiO}_{2}$ nanostructures with high surface area. RSC Adv. 3, 46 (2013)

31. Ko, S.H., Lee, D., Kang, H.W., Nam, K.H., Yeo, J.Y., Hong, S.J., Grigoropoulos, C.P., Sung, H.J.: Nanoforest of hydrothermally grown hierarchical $\mathrm{ZnO}$ nanowires for a high efficiency dye-sensitized solar cell. Nano Lett. 11, 2 (2011)

32. Park, J.T., Koh, J.H., Seo, J.A., Kim, J.H.: Formation of mesoporous $\mathrm{TiO}_{2}$ with large surface areas, interconnectivity and hierarchical pores for dye-sensitized solar cells. J. Mater. Chem. 21, 44 (2011)

33. Cao, F., Wu, X., Xin, S., Guo, Y., Wan, L.: Facile synthesis of mesoporous $\mathrm{TiO} 2-\mathrm{C}$ Nanosphere as an improved anode material for superior high rate $1.5 \mathrm{~V}$ rechargeable $\mathrm{Li}$ ion batteries containing LiFePO4-C cathode. J. Phys. Chem. C 114, 22 (2010)

34. Sivakumar, S., Selvaraj, A., Ramasamy, A.K.: Photocatalytic degradation of organic reactive dyes over $\mathrm{MnTiO} / \mathrm{TiO} 2 \mathrm{Hetero}-$ junction composites under UV-visible irradiation. Photochem. Photobiol. 89, 5 (2013)

35. Luo, Y., Jiang, J., Zhou, W., Yang, H., Luo, J., Qi, X., Zhang, H., Yu, D.Y., Li, C.M., Yu, T.: Self-assembly of well-ordered whisker-like manganese oxide arrays on carbon fiber paper and its application as electrode material for supercapacitors. J. Mater. Chem. 22, 17 (2012)

36. Sadhu, S., Jaiswal, A., Adyanthaya, S., Poddar, P.: Surface chemistry and growth mechanism of highly oriented, single crystalline $\mathrm{TiO} 2$ nanorods on transparent conducting oxide coated glass substrates. RSC Adv. 3, 6 (2013)

37. Chen, H., Kuang, D., Su, C.: Hierarchically micro/nanostructured photoanode materials for dye-sensitized solar cells. J. Mater. Chem. 22, 31 (2012)

38. Ameri, M., Samavat, F., Mohajerani, E.: A semi-empirical analysis of dye adsorption and electron transport in dye sensitized solar cells (DSSCs). RSC Adv. 5, 112 (2015)

39. Sherkar, T.S., Momblona, C., Gil-Escrig, L., Ávila, J., Sessolo, M., Bolink, H.J., Koster, L.J.: Recombination in perovskite solar cells: significance of grain boundaries, interface traps, and defect ions. ACS Energy Lett. 2, 5 (2017)

40. Maitra, S., Pal, S., Datta, S., Maitra, T., Dutta, B., Roy, S.: Nickel doped molybdenum oxide thin film counter electrodes as a lowcost replacement for platinum in dye sensitized solar cells. Mater. Today Proc. (2020). https://doi.org/10.1016/j.matpr.2020.07.531

41. Milan, R., Selopal, G.S., Epifani, M., Natile, M.M., Sberveglieri, G., Vomiero, A., Concina, I.: ZnO@ $\mathrm{SnO} 2$ engineered composite photoanodes for dye sensitized solar cells. Sci. Rep. 5, 1 (2015)

Publisher's Note Springer Nature remains neutral with regard to jurisdictional claims in published maps and institutional affiliations. 